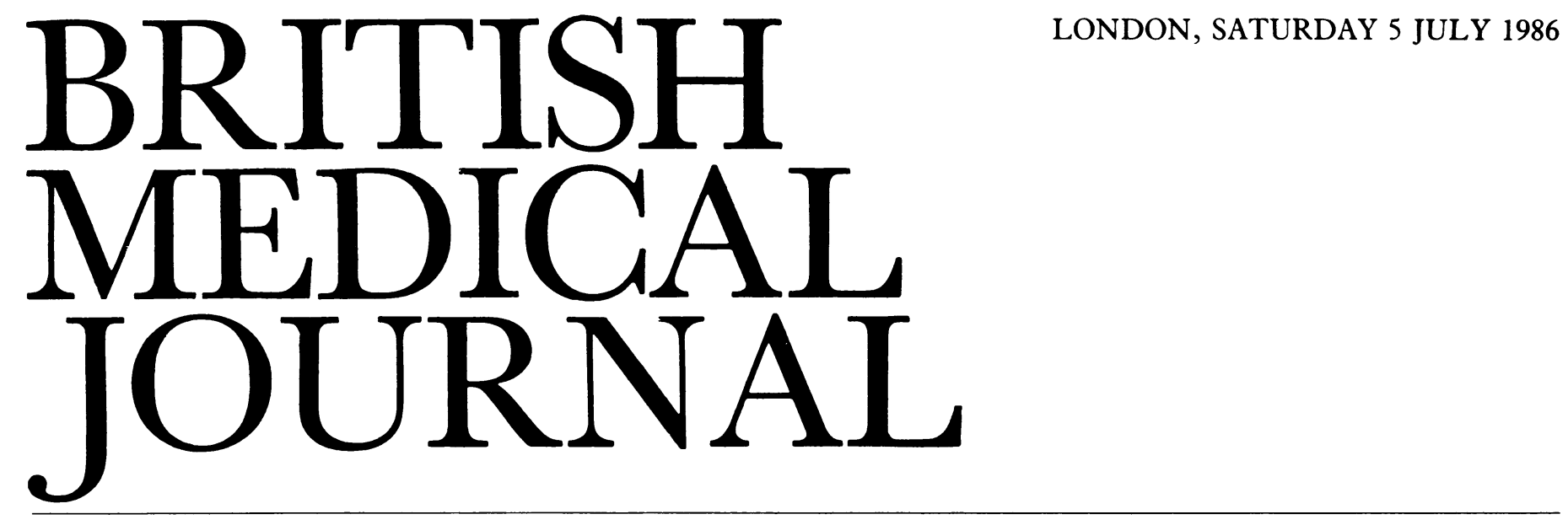

\title{
Aspirin for unstable angina?
}

Some patients recognise their angina like an old friend, greeting them after a fixed amount of effort. For others cardiac pain comes out of the blue, heralding myocardial infarction. In between these two well defined manifestations of coronary disease lies the syndrome of unstable angina; it may be formally defined as angina increasing in frequency, intensity, or duration, or rest pain lasting for at least 15 minutes without evidence of infarction. ${ }^{1}$ Informally patients complain that their pains have become unpredictable.

Nothing exceptional is to be seen in the angiographic pattern of coronary artery disease in patients who have suffered unstable angina,,$^{2-4}$ but angiograms taken before and after the episode are more likely to show progression of the disease than control films taken from patients whose angina has remained stable. ${ }^{56}$ If angiography is undertaken during an attack of unstable angina the appearance of the coronary lesions may be unusual in that the stenoses seem eccentric with irregular borders ${ }^{7}$ and, sometimes, with intraluminal thrombus. ${ }^{8}$ These angiographic appearances correlate with the pathological complications of atheroma such as rupture of plaques and of thrombus formation. ${ }^{9}$ Necropsy examination of patients who have died suddenly with what their relatives describe as episodic chest pain has confirmed that the basis for this syndrome is likely to be change in an atheromatous plaque, with rupture or fissuring of the covering endothelium. ${ }^{10}$ This study also showed platelet emboli in the myocardium downstream from the atheroma, suggesting that unstable angina may be the cardiac equivalent of transient cerebral ischaemic attacks associated with carotid atheroma. ${ }^{10}$

What actually triggers the onset of unstable angina or fissuring of the coronary atheroma is uncertain. A reduction in coronary flow has been shown in angina at rest, ${ }^{11}$ and this may be due to vasospasm. ${ }^{12}$ The evidence that platelets may play a part in the aetiology is rather more convincing, both because intracoronary thrombi are present in unstable angina $^{810}$ and because altered platelet behaviour can be shown in coronary disease ${ }^{13}$ and acute vascular events. ${ }^{14}$ In patients with unstable angina increased concentrations of the platelet specific protein $\beta$ thromboglobulin are found in peripheral blood, ${ }^{15}$ and there is a rise in the concentration in the coronary sinus of thromboxane $\mathrm{B}_{2}$, another indicator of platelet activity. ${ }^{16}$

Possibly spasm of the healthy part of a coronary artery containing an eccentric atheromatous plaque may cause cracking of the plaque surface, aggregation of platelets, new thrombus formation, further occlusion of the lumen, reduction in flow, and distal platelet emboli leading to cardiac pain. Given that this sequence of events is correct the next question becomes whether it should affect management.

The first task in the management of patients with unstable angina is to relieve their pain and anxiety. Rest, nitrates, $\beta$ blockade, and some sedation achieve these aims-largely by reducing cardiac work, though nitrates will also reverse any coronary spasm. Urgent angiography (with a view to angioplasty or bypass surgery) is being recommended and practised with enthusiasm in the United States, Germany, and some centres in Britain. ${ }^{17}$ Dramatic results may apparently be achieved, but this energetic (and expensive) practice cannot be recommended on the strength of published experience. Angioplasty and surgery should be reserved for those patients with persisting angina despite full medical treatment.

The second task is to improve prognosis after the acute episode. In Fulton's classic study of 167 patients with unstable angina 23 went on to develop cardiac infarction and five died within three months. ${ }^{18}$ Other studies have confirmed that most patients will survive in good health, but the mortality after one year is still a worrying $10 \%{ }^{17}{ }^{19}{ }^{20}$; a few more patients will suffer myocardial infarction and survive but with a poorer prognosis. Attempts to identify those most at risk have proved disappointing. ${ }^{21}$ Among the clinical predictors recurrent pain seems to be a clue, ${ }^{20}$ thus reinforcing the need for angiography in these patients.

The belief that platelets may play a part in the aetiology of unstable angina has prompted the use of drugs, such as heparin and aspirin, which modify platelet behaviour. The clinical impression that heparin helps in the management of the acute symptoms has received support from the work of Telford and Wilson, who showed that patients receiving heparin were less likely to develop myocardial infarction in hospital. ${ }^{22}$ So far so good; but what do we do when the heparin has to be stopped?

In studies on animals aspirin reduces platelet aggregation in partially obstructed vessels. ${ }^{23}$ In clinical practice two careful studies have now confirmed that maintenance treatment with aspirin reduces the risk of subsequent cardiac events in patients who have suffered an episode of unstable 
angina. ${ }^{124}$ Both studies were multicentre, randomised, and double blind. In the Veterans' Administration study of 1266 men buffered aspirin $325 \mathrm{mg}$ daily was compared with placebo, ${ }^{1}$ whereas in the Canadian study the 555 patients received aspirin $1300 \mathrm{mg}$ daily, sulfinpyrazone $800 \mathrm{mg}$ daily, or both, or neither. ${ }^{24}$ Patients were entered into the trials by 51 hours and eight days after admission respectively. In the Veterans' study there was a $51 \%$ reduction in death or acute myocardial infarction in the active treatment group at 12 weeks. The Canadian study found an identical reduction in the aspirin treated groups compared with the others after 18 months' follow up; the absolute numbers in the groups receiving aspirin either alone or in combination were 17 cardiac deaths or non-fatal myocardial infarcts out of a total of 276 patients compared with 36 events in 279 patients in the other groups. In both studies the patient groups were comparable and similar to those patients seen elsewhere; for example, the mortality for the untreated patients in the Veterans' study who were followed up for one year was $9 \cdot 6 \%$. In both studies withdrawals were few, and the incidence of side effects in the various groups was similar apart from the increased frequency of gastrointestinal symptoms in those taking aspirin in the Canadian study.

So for our patients with unstable angina medical management remains appropriate; only those with persisting pain need be referred for angiography. For subsequent treatment a credible maxim might be that a coated or buffered aspirin a day keeps the coronary at bay.

Consultant Cardiologist,

M C PETCH

Consultant Cardiologist,
Regional Cardiac Centre,

Papworth Hospital,

Cambridge CB3 8RE
1 Lewis HD, Davis JW, Archibald DG, et al. Protective effects of aspirin against myocardial infarction and death in men with unstable angina. N Engl I Med 1983;309:396-403.

Fischl SJ, Herman MV, Gorlin R. The intermediate coronary syndrome, clinical, angiographic and therapeutic aspects. N Engl f Med 1973;288:1193-8.

3 Alison HW, Russell RO Jr, Mantle JR, Kouchoulkos TN, Morasaki RE, Rackley CE. Coronary anatomy and arteriography in patients with unstable angina pectoris. Am $\mathcal{f}$ Cardiol 1978;41:

4 Fuster V, Frye RL, Connolly DC, Danielson MA, Elveback LR, Kurland LT. Arteriographic $\stackrel{Ð}{\varrho}$ patterns early in the onset of the coronary syndromes. Br Heart $\mathcal{F} 1975 ; 37: 1250-5$.

Neill WA, Wharton TP Jr, Fluri-Lundeen J, Cohen IS. Acute coronary insufficiency-coronary occlusion after intermittent ischaemic attacks. N Engl J Med 1980;302:1157-62.

6 Moise A, Theroux P, Taeymans $\mathrm{Y}$, et al. Unstable angina and progression of coronary atherosclerosis. N Engl I Med 1983;309:685-9.

7 Ambrose JA, Winters SL, Stern A, et al. Angiographic morphology and the pathogenesis of unstable angina pectoris. Foumal of the American College of Cardiology 1985;5:609-16.

8 Holmes DR Jr, Hartzler GO, Smith HC, Fuster V. Coronary artery thrombosis in patients with unstable angina. Br Hear f 1981;45:411-6.

Levin DC, Fallon JT. Significance of the angiographic morphotogy of localised coronary stenosis Histopathological correlations. Circulation 1982;66:316-20. Histopathological correlations. Circulation 1982;66:316-20.
10 Davies MJ, Thomas AC. Intramyocardial platelet emboli in unstable angina and sudden ischaemic
death (abstract). Br Heart $\mathcal{J}$ 1985;54:636.

11 Chierchia S, Brunelli C, Simonetti I, Lazzari M, Maseri A. Sequence of events in angina at rest: primary reduction in coronary flow. Circulation 1980;61:759-68.

12 Maseri A, L'Abbate A, Baroldi G, et al. Coronary vasospasm as a possible cause of myocardial $\frac{\bar{\omega}}{\bar{D}}$ infarction: a conclusion derived from the study of "preinfarction" angina. N Engl $\mathcal{G}$ Med $\overparen{D}$ 1978;299:1271-7.

13 Haft JI. Role of blood platelets in coronary artery disease. Am $\mathcal{f}$ Cardiol 1979;43:1 197-206. 13 Haft JI. Role of blood platelets in coronary artery disease. Am $\mathcal{F}$ Cardiol 1979;43:1 197-206.
5):13-8.

15 Smitherman TC, Milam M, Woo J, Willerson JT, Frankel LP. Elevated beta thromboglobulin in peripheral venous blood of patients with acute myocardial ischaemia: direct evidence for enhanced platelet reactivity in vivo. Am $\mathcal{F}$ Cardiol 1981;48:395.

16 Hirsch PD, Hillis LD, Campbell WB, Firth BG, Willerson JT. Relese of prostaglandins and thromboxane into the coronary circulation in patients with ischaemic heart disease. $N$ Engl $\mathcal{F}$ 윽 Med 1981;304:685-91.

17 Rahimtoola SH. Coronary bypass surgery for unstable angina. Circulation 1984;69:842-8.

18 Fulton M, Lutz W, Donald KW, et al. Natural history of unstable angina pectoris. Lancet

19 Schroeder JS, Lamb IH, Harrison DC. Patients admitted to the coronary care unit for chest pain: Of high risk subgroup for subsequent cardiovascular death. Am $\mathcal{F}$ Cardiol 1977;39:829-32.

20 Mulcahy R, Daly L, Graham I, et al. Unstable angina: natural history and determinants of $@$ prognosis. Am $\mathcal{J}$ Cardiol 1981;48:525-8.

21 Duncan B, Fulton M, Morrison SL, et al. Prognosis of new and worsening angina pectoris. BrMed $\mathrm{O}$ f 1976;i:981-5.

22 Telford AM, Wilson $C$. Trial of heparin versus atenolol in prevention of myocardial infarction in $G$ intermediate coronary syndrome. Lancet $1981 ; \mathrm{i}: 1225-8$.

23 Folts JD, Crowell EB Jr, Rowe GG. Platelet aggregation in partially obstructed vessels and its elimination with aspirin. Circulation 1976;54:365-70.

24 Cairns JA, Gent $M$, Singer J, et al. Aspirin, sulfinpyrazone or both in unstable angina. N Engl $f \vec{\bullet}$ Med 1985;313:1369-75.

\section{Use of molar units for drugs and toxins?}

The chemical, physiological, and pharmacological activity of any natural or artificial constituent of body fluids (and its comparison with the activity of similar constituents) is almost always directly related to the concentrations of the relevant molecules, radicals, or ions expressed in amount of substance (mole) units, and not to the concentrations in mass units such as grams. The $B M \mathcal{F}$ made the change from using mass concentrations to (amount of) substance concentrations in 1975; but this change implies more than just a switch in numerical values, as in converting from calories to joules. The use of molar units requires a conceptual change in dimensions, for when using moles we are in effect counting the number of relevant functioning entities-for example, one molecule, one receptor site. Both substance concentrations and mass concentrations, - usually per litre, are part of the Système International d'Unités (SI), each to be used when most appropriate; in popular medical jargon, however, "SI" has come to mean the preferential use of substance concentrations, typically as $\mathrm{mmol} / 1$.

In most medically advanced countries, including Britain, the results of assay of almost all substances in plasma (or other body fluids) are quoted as substance concentrations if they are naturally occurring constituents of the body and have a known relative molecular mass. The main exception has been the plasma proteins, but the changeover has started for them. There has been no move to abandon the advantages of this system and return to mass units, for this would now be regarded as a retrograde step; the biological importance of the concept of the mole is taught from schooldays. The initial British recommendations did not, however, give guidance for plasma (or urine) constituents that were not normally present, particularly drugs and toxins. ${ }^{1}$ So we have the $\dot{\delta}$ anomaly that in patients plasma lactate and cholesterol concentrations, for example, are measured in $\mathrm{mmol} / \mathrm{l}$, while 은 plasma salicylate and ethanol concentrations are usually $\tilde{N}^{\circ}$ measured in $\mathrm{mg} / \mathrm{dl}$-and some drug concentrations are $\rightarrow$ confusingly given per millilitre. In pharmacological research substance concentrations for drugs are already widely used, $\tilde{\mathrm{N}}$ particularly in experimental animals.

In the United States the American Medical Association has now decided to recommend the change from using mass concentrations to substance concentrations. ${ }^{2}$ These inten- $\frac{\bar{D}}{\mathbb{D}}$ tions will extend both to natural constituents and to drugs. $\stackrel{?}{+}$ The time seems right, therefore, to plan the change for drug ${ }_{0}^{\circ}$ and toxin concentrations in Britain, ${ }^{3}$ and the Association of $\frac{0}{\mathbb{D}}$ Clinical Biochemists has issued recommendations for drugs. ${ }^{4} \stackrel{\overbrace{}}{\mathbb{\Phi}}$ These read: "Rationalisation is paramount in the interests of $\frac{\varnothing}{\sigma}$ patient safety. The units adopted should be based on the litre as the unit of volume. As no particular unit is used by a substantial majority of laboratories, molar units should be the units of choice because of the strong scientific arguments $\frac{0}{2}$ in their favour." 